\title{
SPIRITUALITY, THEOLOGY AND THE CRITICAL MIND
}

\author{
P.G.R. de Villiers ${ }^{1}$
}

\begin{abstract}
This essay investigates aspects of the critical nature of spirituality as a discipline. It first analyses how a recent publication on philosophy critiques the role of the critical mind in contemporary philosophy and how it reclaims spirituality as solution for what went wrong. In a next section it discusses similar criticism of traditional theology and spirituality by Contextual Theologies and points out the development of Contextual Spiritualities as a critical response and solution to what went wrong. It finally focuses on the selfimplicating nature of the critical mind in terms of the spirituality of the researcher as a safeguard against such excesses and against the deformation of the critical mind.
\end{abstract}

\section{INTRODUCTION}

There is a perception among some critical thinkers that theology ${ }^{2}$ is characterised by the demand to accept, confess and defend certain orthodox propositions and contents as absolute and eternal "truths" to which the critical mind has to subject itself, thus sacrificing or com-

1 Prof. Pieter G.R. de Villiers, Professor Extraordinarius in Biblical Spirituality, Department of New Testament, University of the Free State, Bloemfontein (pgdevilliers@ mweb.co.za). This essay was presented in parts at the inaugural meeting of the Spirituality Association of South Africa (SPIRASA) in Stellenbosch (2004) and at the Socratic Society of the University of Namibia in Windhoek in August 2005. I especially thank the participants in the latter meeting for their meaningful input during the discussion of my contribution.

2 The widely discussed notion of theology is used in this essay to refer, amongst others, to beliefs, propositions or in a general sense to what is believed. Cf. the discussion by McGrath (1999:25) who notes that

perhaps the simplest way of characterizing the relation between theology and spirituality is to suggest that the former is about theory, and the latter the practice, the Christian life.

It is obviously a simplification, as the following essay will indicate. Although they can be distinguished in this way, they cannot, and should not, be separated. 
promising its intellectual integrity. To the critical mind this is in conflict with the Socratic principle of discovering truth through analytical, dialectical discussion. The Socratic approach asks for dialogue, for comparing different perspectives, so that one then has the freedom to change one's mind about such issues in the light of this explorative approach. Such thinkers demand space to construct a meaningful perspective on life in the light of new insights generated especially in science. The critical mind believes that it is vital to enjoy this freedom since it allows for progress and generates a proper and adequate understanding of life and the world.

This perception of theology as a threat to the inquisitive mind is not new and is also not imaginary. The often closed, authoritarian character of official church teaching is well documented in the history. The fate of Galileo, and of many other thinkers after him, illustrated the oppressive power of the church over those who pursued scientific enquiry and promoted critical knowledge that deviated from what was acceptable and standard teaching.

This development has coincided with another interesting phenomenon, namely criticism of the critical mind itself. Not the threat to the critical mind is then in focus, but the problems inherent in it are then pointed out. In this movement, negative aspects of the critical mind and the unattractive results of critical thinking in contemporary discourses are discussed. A recent publication by a leading philosopher will illustrate both these points in more depth. This publication is so much more relevant because it focuses on spirituality as the discipline in which the truly critical mindset finds its true and original home.

\section{CRITIQUE OF CONTEMPORARY PHILOSOPHY}

In a publication with the title, Spiritualiteit voor sceptici, ${ }^{3}$ the North American philosopher Robert Solomon $(2002: 19)^{4}$ provides a surpri-

3 The quotations in this essay are taken from the Dutch translation. The English edition, titled, Spirituality for the skeptic, was unfortunately not available to the author of this essay.

4 Solomon, known for his publication, Above the bottom line, has an interesting record of approaching business from an Aristotelian perspective and for his reflection on existential thinkers and issues. 
singly negative evaluation of contemporary philosophy. He argues that it had become an uninteresting, technical discipline in which students, who should study philosophy in pursuit of the Socratic ideal of discovering the meaningful in life, are instead confronted with hair splitting arguments about technical issues. As a result, contemporary philosophy has little or no influence in academic, cultural and intellectual life (Solomon 2002:47; cf. 19-20). It is not making the slightest difference in how its students experience life and the world. In its intellectualism and in its reduction of its focus to the rational and its exclusion of the emotional side of life, ${ }^{5}$ it has lost a transformative power (Solomon 2002:19).

He points out that this decay in philosophical discourse is due to the fact that it had been cut off from its original social roots as the open and public quest for wisdom. ${ }^{6}$ Philosophy then was not the domain and privilege of the individual scholar, arguing about ideas and concepts (Solomon 2002:46), but a dialogue between people about meaning (Solomon 2002:61). In contrast to this original setting, contemporary philosophy is no longer humble enough to listen to people who are not as bright as some philosophers think they are and who found answers to life elsewhere and formulated them differently.

This original setting presented a more comprehensive approach to wisdom than mere objective, rational enquiry. The issue is not the quest for truth and the place of reason, since it goes without saying that truth should be pursued in a rational, reflective manner. It is rather that this quest no longer reflects the original powerful ability of phi-

5 "De filosofie ging volstrekt voorbij aan de emotionele kant van het menszijn" (Solomon 2002:19).

6 Zonder spiritualiteit is de filosofie niets dan raadsels, ongetwijfeld opwindende raadsels, maar tog gewoon raadsels, die vervreemd zijn geraakt van een groter publiek en ontdaan van persoonlijk gevoel. Net als de theologie moet die filosofie iets van de persoonlijke charme van mythe en mythologie terugwinnen (Solomon 2002:62).

Cf. also his reference to the puzzle solving of contemporary analytic philosophy and the often cynical obscurantism of many contemporary continental philosophies (Solomon 2002:63). Note, finally, his remarks:

Ik (wil) vooral alle slimme filosofie op afstand houden die spot met grote vragen of ze reduceert tot louter raadsels en paradoxen (Solomon 2002:29). 
losophy to integrate the rational and the passionate - as the famous example of Socrates in whose life reason and eros were intertwined, proves (Solomon 2002:62). Thus Plato spoke about the passion for truth in erotic terms, whilst other thinkers (e.g., Augustine) similarly stressed the passions that lead to truth. ${ }^{7}$ The passions and mind were thus involved in matters like the meaning of life, tragedy, death, self consciousness and philosophy itself. As solution to the problem of rationalistic philosophy, Solomon argues that philosophy should return to its spiritual roots. Of course it is also interested in truth and fascinated by riddles and paradoxes, but ultimately its interest in these and its overall activity wanted to addresses the more comprehensive and fundamental question of the meaning of life. All this is confirmed by someone like Nietzsche who rejected a philosophy that is reduced to epistemology as a philosophy on its last legs. Philosophy thus is not about knowledge as knowledge. Philosophy cannot be meaningful if it consists only of rational thinking, because it reduces life to a cerebral matter and excludes major aspects of being human (Solomon 2002:28). The reflective is part of a larger quest for spirituality — as is best illustrated by Solomon's description of spirituality as the thoughtful love of life (2002:28-30). ${ }^{8}$

This reflection of Solomon is an indication of the second part of the problem discussed in the introduction above, namely how rationality and the critical mind in itself can obtain and display a negative character. It is therefore not analytic thinking, the rational dialogue that is decisive; it is rather its function and the framework in which it is embedded that matters. More than mere critical, rational thinking is needed to think and live meaningfully.

Interesting now is how Solomon argues that philosophy is related to religion or theology, thereby addressing the other side of the problem mentioned above. Spirituality must be reclaimed by philosophy from religion that reduced spirituality to the acceptance of doctrine (Solomon

7 In the Symposium Socrates and Plato developed love as the passion that makes life meaningful and that brings the I in contact with a greater, brilliant cosmos (Solomon 2002:67). Thinkers of later, more modern times like Goethe, Hegel, Kierkegaard and Nietszche also continued this line of investigation.

Which is also the subtitle of his publication. 
2002:40-41). Groups who reduce religion or spirituality to doctrine (e.g., creationism), create a tragic, unnecessary and superficial conflict between spirituality and science. They fail to see that these two reflect completely different perspectives on life that has nothing to do with alternative epistemologies. Doctrine is used by these groups to generate a system of knowledge that opposes that of science or philosophy. In contrast to this, spirituality should not be regarded as primarily about propositions, even if some propositions do function in it. Spirituality is a way (or ways) of experiencing the world, life and the interaction with other people and the world - which is what philosophy is all about. Solomon wishes to overcome an excessive rationalism in contemporary philosophy by moving away from propositions, or objective contents, to relationality, as it is promoted in spirituality. $\mathrm{He}$ (Solomon 2002:38) notes:

Maar spiritualiteit althans is nie primair een kwestie van overtuig-
ingen (hoewel er zeker overtuigingen aan te pas komen). Eerder is
het een manier (of een aantal manieren) van het ervaren van de wereld,
van het leven, van de wisselwerking met andere mensen en de wereld
(secondary italics).

And observes elsewhere about spirituality as an activity (not a cerebral thought system):

Het beste deel van religie is juist spiritualiteit, en de kern van spiritualiteit is een oprechte activiteit die vervuld is van intelligente gevoel, handeling, rede en passie (Solomon 2002:45; secondary italics).

This important publication thus defends the critical mind against a closed system of thought, but it also criticises a critical mind that has become disembodied from its life-creating setting. In this rejection of religious spirituality that is too propositional in nature or of philosophy as ignoring the essential and wider framework in which it is embedded, one could quote similar observations by theologians who felt the same way — as now needs further explanation. 


\section{CRITICISM OF TRADITIONAL THEOLOGY}

In his magisterial work on spirituality, Waaijman (2002:311) draws attention to the subject of "spiritual theology" about which he writes:

In traditional theology the academic discipline of spirituality was subject to the dominance of dogmatics and morality, the content of which it was supposed to interiorize.

Here spirituality was studied in terms of theology, propositions and contents. This represented the problem discussed in the introduction above, as was clear from the fact that it was unacceptable to many. Thus a backlash soon set in, so that, as Waaijman continues to note:

[I]n recent decades, however, it (spirituality) detached itself from its traditional-theological setting ... in order to ... become an independent, non-theological ... discipline.

But, this development is not without its problems. Waaijman thus (2002:311) asks:

The question, however, is whether the study of spirituality does not have too stereotypical a view of theology, a discipline which has changed over the years. Theology is often portrayed, caricature-like, as abstract, impersonal, technical, dogmatic, systematic in an old-fashioned way, sterile, one-dimensional. Does this image correspond to what we actually find in today's theology?

This is a remark that deserves further discussion now - both in terms of theology in general and in terms of spirituality specifically. There are some significant trends in modern theology that illustrate the observation of Waaijman about a too stereotypical view of theology. Given the limited space in this essay, only one example of this trend, reflected in contextual theologies and spiritualities, can be discussed in detail. This will illustrate not only that theology should not be stereotyped too facilely as being technical and dogmatic, but also that theology can function in some forms of spirituality in a liberating, critical and creative manner where the critical mind can feel at home.

9 Cf. Waaijman (2002:381-3) for spiritual theologies as a more detailed example of this. He refers to Meynard, Tanquerey and Auman as proponents of these theologies and summarises them: "Spirituality is viewed as the appropriation of a certain sphere of ideas and values." 
During the last three decades of the twentieth century, a notable change began to take place within theology in a movement best described as contextual theologies. This movement is characterised by similar developments such as Feminist Theology, Political Theology in Western Europe, Liberation Theology in South America, Black Theology in the United States and in Africa and others (like Min-Jung theology in Korea), with recently Queer Theory, Postcolonial Theory and Intercultural Readings. ${ }^{10}$ These contextual theologies share some commonalities like a similar methodology (cf. below on the see-judge-act approach) and similar characteristics, like focussing on societal structures and their transformation. But they, more importantly for this essay, also all share a rejection of the traditional Western theology because of its abstract, idealistic and rationalistic character.

Traditional Western theology is criticised for having lost its dynamic, transformative nature and for indulging in debate about irrelevant dogmatic or exegetical intricacies — what Solomon also criticises in many forms of traditional philosophies. ${ }^{11}$

In reaction against this idealist and objectivist approach, contextual theologies stressed the need for theology to be transformative in order to eradicate injustice and inequality. ${ }^{12}$ They questioned the ethical nature of a discipline that restricted itself to being a non-involved, object study of Scripture and of reflections on it. They observed that whilst theologians indulged in intricate theological discussions, exploitative

10 Schneiders (1990:20); Roten (1994:104). For some general introductions to these varied movements, cf. Amirtham \& Pryor ([1989]; 1994); Astell (1994a and 1994b); Boff (1984); Bussmann (1985); Cady, Ronan, \& Taussig (1986); Caprio (1982); Croatto (โ1989]); Min (1989); Rayan (1992); Sobrino (1984 and 1985); Verhoeven (1989); Rhoads (2004).

11 In this sense one could feel the presence of an interdisciplinary phenomenon that points to the limitations and restrictions of a paradigm of thought that developed in Western thought especially since the Enlightenment. Solomon (2002: 46) notes that the threat in contemporary thought to genuine forms of religion and spirituality is a result of Western Enlightenment — with all the negative consequences to philosophy that came with this. There are other interesting indications of this interdisciplinary trend, like the seminal studies of Nussbaum (1986; 1994) (on passions in antiquity).

12 For a discussion of this, cf. De Villiers (1993:1-28; 1999a and 1999b). 
societal structures and problems like abysmal poverty continued unabatedly. The same was also true in the case of the holocaust which took place in the erudite context of Christian Germany during the Second World War. Traditional theology created conditions for practices like these because of its claims to "objectivity" and distance between the researcher, the theologian, and theology's source or object of study, the Bible.

This was a major development in theology, since contextual theologies completely reversed the intellectual practice and methodology. Whilst much of traditional Western thought reflected on abstract ideas and claimed an objective historical approach, ${ }^{13}$ contextual theologies implemented exactly the opposite approach, following what was known as the see-judge-act model. Moving first from a critical analysis of the life setting in which the religious person finds her- or himself, they then take a second step, reflecting on ways and means to transform these structures. One would mostly read the Bible and reflect on it in this phase in so far as it provided relevant material. In a third phase there is concrete, practical action - which is the thrust of the theological enterprise.

This general development also characterised the study of the Bible. Biblical Studies, especially in Western Europe, displayed an increasingly rational character with certain scientific approaches that emphasised that the Bible is a book like any other book and that should be studied in the same manner as those books. During the twentieth century this resulted in detailed technical discussion about the historical nature of the Bible. An early symptom of this research is the wellknown dictionary on the New Testament of Gerhard Kittel with its historical approach, but also, significantly, with its reading of Biblical material in terms of abstract ideas and topics. As a new academic discourse, the so-called historical-critical study of the Bible correctly challenged the unacceptable grip of church doctrine on the discipline. In doing so, it often eliminated a faith perspective on the Bible as un-

13 Note the similar and apt insights of McGrath (1999:27), who writes:

The Enlightenment held that any form of religious commitment was an obstacle to objectivity, and thus cultivated the idea of religious neutrality in theology .... The outcome of this is that "theology" has often been conceived as the academic study of religious concepts, with no connection to Christian life as a whole (secondary italics). 
desirable instead of reforming or remodelling the faith perspective. It also reduced the interpretation of the Bible to the study of historical phenomena. ${ }^{14}$ Contextual Bible readings wanted to correct this by pointing out how decisively such limited readings affected society and the church.

Recently this insight was reiterated in mainstream Biblical scholarship when Rhoads (2005:6) noted, not without irony, some of the above insights:

\begin{abstract}
Although Western scholarship has historically been aware of the biases of religious doctrine and the presuppositions of a modern scientific worldview, most scholars were generally unaware of the extent to which fundamental factors of cultural and social location had shaped, distorted and limited their interpretations and methods. Furthermore, because of the power of Western societies, these situated interpretations have been appropriated to justify conquest, destruction, and domination over cultures, subcultures, and social groups both within and outside the Western world.
\end{abstract}

Contextual theologies are thus part of a wider, comprehensive revision of a particular type of theology that originated and functioned in Western Europe mainly since the Enlightenment. It emphasised the need to relate theology to praxis and for this practice to be efficacious and transformative. It reveals how dynamic theology can be and how a theology that is radically different from its predecessors can be generated by a new context and a critical mindset, confirming the observation of Waaijman noted above.

Once again, the problem was not so much the critical mind that was operative in traditional theologies. Contextual theologies do not reflect any reservations about this. It was rather a matter of the nature of the technical debates. Their outcomes and their seemingly lack of integration in a life setting stripped the critical mind of its dynamic nature, but more importantly, it failed to recognise important aspects of the critical mind - as now needs more explanation.

14 For an extensive discussion, cf. Rhoads (2005:1-27). 


\section{DESIGNING NEW FORMS OF SPIRTUALITY}

Soon, though, the practical, societal focus of contextual theologies on political and structural transformation raised some critical questions, confirming not only the ongoing critical mindset, but also the dynamic nature of these theologies. There were the simple, straightforward questions: what would be the function of religion once women were empowered, poverty eliminated and racism overcome? Also important were questions about the nature of the transformation of society. Apprehensive that liberation from the oppressing structures would create other oppressors in their place, these theologies were further pushed to reflect on the deeper issues like spiritual values, ideals and norms that they strived for and on the nature of the truly transformative spirituality that they claimed to promote (cf., e.g., Boff 1984; Sobrino 1984). ${ }^{15}$ Thus a critical approach urged theologians to reconsider the contents and nature of their theological activity.

\subsection{Broadening theology into spirituality}

As a result many of these contextual theologians started developing contextual spiritualities. Early on Liberation theologians moved on to write on liberationist spirituality (e.g., Boff 1984; Galilea 1988). Feminist spiritualities, complementing feminist theologies, became a much discussed topic in recent years (cf., e.g., Jantzen 1995). ${ }^{16}$ These movements focused on religious aspects that relate to the experience of faith. Schneiders' comment (1995:17), "Only theology that is oriented

15 Waaijman (2002:218) notes in his discussion of Latin American spirituality of liberation how spiritual praxis is intrinsically determined by social praxis.

Within spiritual/intellectual praxis the analysis of social structures, the option for the oppressed and personal involvement in processes of change constitute an ever-recurring triad.

In the case of Black spirituality he notes that "practical charity and political involvement essentially belong together" and refers to the special role of prayer in it. Waaijman correctly points out motifs of spirituality in these two forms of contextual theology, but the move to a more explicit reflection on spirituality is a bit more complicated. It represents a later development in which contextual theologians responded against accusations that they were politicising Christianity. For the latter, cf. esp. Boff (1984) and its telling title.

16 For a discussion, cf. De Villiers (1999a and 1999b.) 
toward praxis will be meaningful in the Church of the future," now had to be developed further. This theology was described as spirituality - but spirituality was now no longer identified with an individualistic, ascetic focus only on the "interior life" of prayer and spiritual exercises. It

connotes the whole of the life of faith and even the life of the person as a whole, including its bodily, psychological, social and political dimensions (Schneiders 1990:19).

With this insight, the social and political dimensions are integrated in a wider faith-orientated framework. How widespread this was, is illustrated by a recent publication on spirituality in an Asian context that contains contributions on spirituality in the Korean Minjung tradition, while it looks at quests for spirituality in Indonesia, India, the Philippines, Hong Kong and Sri Lanka and to different societal groups and issues in these countries. Similar feelings than those of Schneiders were expressed by Fabella, Lee \& Kwang-Sun (1992:76), who wrote:

\begin{abstract}
Spirituality has ... come to be looked upon as world-negating, nonhistorical, non-political, and hence as something private, subjective, and pacifying; it has to do with an important segment, but a segment of life, and is unrelated to the rest. This restrictive, reductionist, and dualist view of spirituality we reject.
\end{abstract}

As a result of this development, the liberating and reconstructive nature of spirituality became important. This deserves more attention now, especially in order to show how dynamic the process was, how active the critical mindset functioned and what special understanding of the nature of the critical mindset operated in these theologies.

\title{
4.2 Spirituality as liberating and reconstructive praxis
}

For contextual Christians spirituality is not only an integral part of the struggle for a humane society, but it in fact generates the struggle for the liberation of society from oppressive structures. A brief analysis of the Asian publication reveals what dynamics are introduced by integrating the notion of spirituality in contextual theologies and how the notion of spirituality is developed as a result of this integration. 
Regarding women, for example, the editors remark that in the maleoriented and -dominated Asian societies, they have been severely disadvantaged in terms of their spirituality:

(T)heir education is neglected, their opportunities limited, their role in society restricted. The commercialization of sex has further aggravated women's already subjugated position (Fabella, Lee \& D. Kwangsun Suh 1992:76).

They write that the meeting of twenty men and twenty women debated this situation, with the telling remark added that they then reflected on sexuality as part of spirituality. "The challenge was posed: What has liberation spirituality to say and to do about sexuality in the Asian setting?" (secondary italics; cf. Fabella, Lee \& D. Kwang-sun Suh 1992:7-8).

They then argue that they find the answers to this quest for a specific spirituality in the re-appropriation and reintegration of the Bible from the perspective

of women in struggle, and to give new meaning and courage to women in the midst of their violence-filled lives. A critique of traditional, patriarchal images of God and of Christology and a search for new, more liberative, compassionate, healing, and nurturing images assume significance (Fabella, Lee \& D. Kwang-sun Suh 1992:71; secondary italics). ${ }^{17}$

With remarks like these, contextual theologies take on a new dimension, focusing in their critical reflection on spirituality in order to advance their program further. There is a break with male-orientated notions of spirituality that have a coercive character. ${ }^{18}$ It is not a breaking away from Scripture and tradition, but rather a matter of

17 Note also in this regard Jantzen (1995:17) who observes:
And in biblical studies and theology there has been distinguished work demon- strating how intertwined are the notions of a patriarchal God and the op- pression of women, and how the methods of biblical study and doctrinal for- mulation have rested on assumptions that arise out of and reinforce white male domination, not only of women, but also of other races and cultures and of the earth itself (Ruether 1983; Schüssler Fiorenza 1983).

18 Similar impressive and sophisticated work was done by Jantzen (1995), who showed how traditional spirituality oppressed women by imposing male categories on them. Equally impressive is her outline of examples of how women responded to this exploitation with manipulation in order to assert themselves. 
critically reinterpreting them. Reflection on God and Christ continued in order to characterise the new condition that the proponents of change wish to see in the place of the old, exploitative past. New forms and uses of traditional spirituality categories are sought and explored. They seek to replace the negative with the positive and healing, with Christian images that are compassionate and nurturing to generate an authentic existence of women specifically in an Asian setting. This did not mean, for example, that women wanted to become like men, but they wanted to develop the necessary feminine images for a full, human life in the spirit. To be equal, but different partners of men, implied a creative response from their side — and such creativity illustrates other dimensions of what spirituality is about:

The attempts to draw on creative expressions - dance, drama, poetry, music, art, story-telling, and folklore - to give expression to the new-found consciousness and energy is spirituality (Fabella, Lee \& D. Kwang-sun Suh 1992:71).

And:

In sisterhood, in communal selfhood, in solidarity with all other oppressed people, in the simplicity of the lifestyle of the movement, and in their commitment to healing a wounded creation and wounded world, women are expressing a new spirituality (Fabella, Lee \& D. Kwang-sun Suh 1992:72).

It strikes one how concretely this definition relates to a comprehensive, transformative, relational and healing praxis. ${ }^{19}$ Common humanity is in focus, it must be liberated from what is destructive, relationships must be restored and nurtured to allow each and every one to become and be truly human in her or his own way. Language, images and practices must be life creating for and meaningful to people in their specific contexts. It is not a matter of interiorising a given doctrine, but of critically developing a humane existence before God in terms of tradition, but at times also in a clear distance of its exploitative aspects. ${ }^{20}$

19 These remarks are illuminated further by the understanding of spirituality as proposed by Waaijman (e.g., 2002:305ff.)

20 One could also speak of the usefulness of theology and spirituality - a motif that was important to the Patristic Fathers and taken over recently by some commentators (cf. Decock 2005:66-67). 


\subsection{An engaged discipline}

The engaged nature of contextual theologies discussed in the previous section thus is also true of contextual spiritualities. Both demanded an engagement with the issues of the day.

But there was something more to this that briefly needs to be mentioned here as it has to do with the very nature of spirituality as a discipline and the way in which the critical mind functions in it. Both contextual theologies and spiritualities were apprehensive about studying spirituality mainly in a theoretical way, that is, with an emphasis on "academic mastery of the subject rather than actual (first order) practice" (Maas \& O'Donnell 1990:18; Woordward 1987). ${ }^{21}$ Schneiders (1990:34$35)$, for example, insisted that spiritual practice should not be neglected by the academic study of the field. There are, therefore, conscious attempts to stress its particular methodological style of participation ${ }^{22}$ and to point out that the objective of the discipline is spiritual practice. ${ }^{23}$ This is why some insist that both theoretical discourse on and actual practice in spirituality are retained when the field is studied.

But there was more at stake here. The point is not merely that theory and practice should be kept together. It is more a matter of the role and function of the researcher in the discipline. The one who studies spirituality must remain engaged — not only by asking relevant questions. Some want to distinguish spirituality from other forms of academic discourse by emphasising the unique existential relationship between its subject matter and the one who researches it. In this sense the study of spirituality is then regarded as self-implicating. Thus Hanson (1990:50) wrote:

[S]pirituality is that study whose subject matter is faith and which involves a stance of the subject toward the subject matter that combines hard reflection with a strong existential movement to faith.

This would be in line with the transformative nature of spirituality, since the discipline is then also about the way in which the researcher is involved in and transformed by what is being researched.

21 Note the article of Eire (1990) and esp. MacGrath (1999) on this question.

22 Schneiders (1990:33-34) has some salient remarks on this.

23 These problems address major issues in hermeneutics and in philosophy of science and will be discussed elsewhere. 
Thus the critical self-awareness is built into the activities of the discipline. In academic discourse where the critical mind is clearly active, the researcher's spirituality cannot be left behind or isolated from his or her other faculties. ${ }^{24}$ Other than is often thought, self-implication and an existential relationship to the object of research do not impede scientific enquiry because they would affect rational enquiry negatively - the raison d'etre behind much of Enlightenment thought. Such a view would be a reduction of what actually happens in spirituality and its discipline. Thus Solomon's book on spirituality as the thoughtful love of life, emphasises reflection ("nadenkendheid") and the important place of thoughts about the meaning of life in it, but at the same time it stresses that spirituality is about a life lived according to great thoughts and passions. Spirituality encompasses love, trust, respect and wisdom, but also the terrible aspects of life such as tragedy and death. ${ }^{25}$ This requires of the researcher to take on a spiritual attitude, a certain mentality, a series of emotions, a number of representations ("voorstellingen") that promote and evoke spirituality (Solomon 2002:55). This reflection is characterised by deep emotions (Solomon 2002:29).

In the case of the discipline, this means that the researcher is more irrational when he or she pretends to bracket his non-rational framework within which his or her work is embedded than when he or she consciously embraces and moots it. In spirituality as the thoughtful love of life the one who investigates spirituality is deeply implicated and existentially involved as Solomon (2002:51ff.) insists.

This also means amongst others that the academic teaches what he or she knows is true in his or her life and person, ${ }^{26}$ as has been underlined already by patristic authors. Like contemporary readers' response, the decisive contribution of the interpreter to understanding is underlined by them. Recently Decock (2005:68) pointed out how radically

24 Cf. further on this, Decock (2005:67). He quotes Origen who stated that teachings is not merely about truth, but about becoming followers of the truth.

25 Spiritualiteit betekent voor mij die grote, doordachte passies van het leven, en een leven dat geleefd wordt overeenkomstig die grote gedachten en passies. Spiritualiteit omvat liefde, vertrouwen, eerbied en wijsheid, evenals de verschrikkelijkste aspecten van het leven, tragedie en dood.

26 This is reflected in the insistence of contextual spiritualities that spirituality should have an efficacious nature. 
important they thought the person of the teacher was. Having noted that modernity relies heavily on the "objectivity and conceptual ability" of interpreters, he points out that the Fathers found moral and religious qualities decisive:

As "only like understands like" a reader who is becoming God-like will understand the things of God. Becoming attuned to God required first of all the development of moral quality which made union with God possible. Moral quality and union with God are not just the pre-requisites for understanding, they are part of understanding itself. $^{27}$

It is this last remark that is of special importance. The spirituality of the interpreter is not only needed for understanding, but is all about understanding itself. This is an important contribution to hermeneutics and a necessary complement to readers' response. Recently Waaijman (2002:312) distinguished several levels regarding the relationship between lived spirituality and the study of spirituality. On the most general level there is "an inseparable interwovenness between the world we live in and science." Quoting Schneiders, he notes that living the spiritual life has ontological and existential priority over studying it. "This priority, as pre-understanding, is (co-)constitutive for the understanding (hermeneutics) of the academician" (Waaijman 2002:311). Closely linked to this, the other

level comes into play as we observe how the study of spirituality impacts lived spirituality, since research on spirituality is self-implicating and understanding is transformative.

Spirituality is therefore a research discipline whose ethos is driven by its transformative character and its nature as a discipline which is decisively determined by the spirituality of the one who researches it. Contextual spiritualities thus understood correctly that spirituality needs to be taught with commitment and efficacy, whilst the spirituality of the interpreter is self-implicated and transformative. Spirituality lapses into intellectualism and cold rationalism without this. ${ }^{28}$

27 He quotes some remarks by Origen and then refers to Augustine's insight in the functioning of signs. For Augustine figurative expressions are mediated by the person of the reader.

28 For further arguments, cf. the remarks of Jantzen (e.g., 1995:86-123). She argues that the overt intellectual mysticism of Eckhard and Bernard of Clairvaux in the high 


\section{THE SPIRITUALITY OF THE RESEARCHER}

The above remarks revealed how contextual theologies and spiritualities criticised an intellectualism in traditional theology that focussed on abstract ideas and failed to effectively address exploitation through societal structures, without sacrificing their critical mindset - as is evident from their convincing criticism and arguments against their predecessors. At the same time and with equally critical insights, they creatively generated a new form of engaged theology and spirituality often unlike that of their predecessors. One could point to a Socratic style of critical thought at work here: The traditional point of view within the church was suspended, possible alternatives evaluated and a new direction pointed out that established a new paradigm of thought, but consistently in pursuit of a love of wisdom.

One could speak here of continuity and discontinuity, as was already done to some degree in the above sections. Waaijman (2002:310) addresses this issue when he draws attention to the reflection on lived spirituality that goes back to the first centuries of Christianity. $\mathrm{He}$ noted that contemporary spirituality has "forcibly brought about a large-scale discontinuity vis-à-vis the traditional discipline of spirituality." The question is how the phenomenon of spirituality can be defined now that it has "radically enlarged itself and detached itself from its original context."

Caught up in this ambivalence, scholars may prefer the discontinuity: because spirituality is no longer exclusively Roman Catholic, no longer dogmatic, no longer prescriptive, no longer centered around perfection but around growth, no longer focused on the inner life but on the whole person, a new discipline has to be developed.

He then adds, "One may wonder, however, how strong the epistemological arguments for this discontinuity are."

Middle Ages marginalised women despite much sincere piety. She notes (2002: 100) how "relentlessly cognitive" this mystical theology is, tightly bound up with the hierarchical authority structure of the church and promoted at a high cost for women. Also intriguing is her argument (2002:105-7) that in the case of Dionysius when the mystical path as path of reason collapses and reason is taken beyond itself, it collapses in ignorance and not into love or faith - once again creating particular obstacles for women who were regarded as intellectually inferior. 
This is a remark that deserves close attention, especially since it is necessary to reflect further on the role of the critical mind noted above. In contextual spiritualities, for example, basic concepts continued playing a seminal role, as was noted to some extent earlier on. This is striking, since contextual spiritualities are part of a post-modern era with its rejection of truth as an absolute and with its openness to the construction of new ways of thinking in different contexts. In a collection of essays, written from different doctrinal perspective and thus allowing space for different perspectives, Maas and O’Donnell (1990b:17) clarifies this further:

It is a fallacy to think that we can be spiritual or have a meaningful relationship with God without being concerned about the specifics of doctrine. Our belief system shapes, in a definitive way, our relationship with God.

The challenge is to understand this in the light of what Schneiders (1990:29) wrote about Christian Spirituality as a theological discipline, i.e. a discipline carried out "in the context of explicit reference to revelation and explicitly affirmed confessional commitment" (Schneiders 1990:29). If understood in the wrong way, such a remark could easily bring us back to the position mooted at the beginning of this essay in which theology is pointed out as a threat to the critical mind.

As was noted above, this should rather be understood in the light of the fact that spirituality is not about a given set of beliefs that is interiorised and about abstract ideas that steer and determine it. It is indeed the case that interaction with Scripture and theological insights are retained and both provide inspiration and subject matter to spirituality - questioning the approach in which the discontinuity of contemporary spirituality is emphasised at the cost of continuity. This Biblical and traditional subject matter qualifies spirituality under discussion here as Christian, providing one way of distinguishing it from, for example, philosophical spirituality. This subject matter, furthermore, also moves it in a particular direction without necessarily disqualifying or impeding its scientific or critical nature.

This is further explained and motivated by the values in the subject matter that come to the fore in the study of spirituality. As Macquarrie (1986:585) writes: 
[S]uch a unique and exalted subject-matter demands to be pursued with the utmost intellectual endeavour and the most stringent honesty.

He adds that this requires humility. It points to an intellectual activity that understands the

meaning of metanoia as change of mind and repentance, when their studies lead them to set aside long cherished theories and opinions in the light of fuller truth (Macquarrie 1986:586).

These values thus once again reflect an openness that is close to the Socratic value of subjecting one's own position to critical investigation and revision. In contextual theologies and spiritualities this happened through their see-judge-act-model which points out critical analysis as their point of departure. But the critical mind was also at work as different theological, social and cultural traditions become involved in the pursuit of creative expressions for new forms of spirituality. Thus, in the case of Christian spirituality, there is a mutual relationship between spirituality as an experience of faith inspired by Jesus as expression of the Spirit of Israel's God (Bras 2001:14) and other influences:

\begin{abstract}
$\mathrm{Er}$ is een wisselwerking tussen het algemeen menselijk zoeken zoals dat in allerlei vormen van cultuur en religie vorm krijgt en het specifiek christelijke zoeken naar leven en innige verbondenheid met de Vader van Jezus Christus, de God van Israel. Enerzijds moeten we vasstellen dat de christelijke traditie nog steeds veel invloed heeft op het zin zoeken van de hedendaagse mens. Anderzijds ondergaat deze traditie ook de invloed van hedendaagse maatschaplijke veranderingen en van anders- of niet-religieuze vormen van zin zoeken (Bras 2001:14-15).
\end{abstract}

It is to be expected that the role of theology and tradition in spirituality will vary - in itself an indication of the presence and function of the critical mind in it. Beliefs, as McGrath (1999:28-31), has illustrated in a valuable discussion, can be vital, for example in the case of ecological spirituality. Belief in God as creator "encourages us to affirm and explore the natural world as a way of finding out more about God" (McGrath 1999:30). Beliefs thus would shape spirituality. But McGrath also points out the opposite dynamics that are operative in spirituality. He notes how Christian worship and prayer impacted on belief when, in Arian controversy, the worship of Christ determined the understanding of the identity and significance of Jesus (McGrath 
1999:30-31). Ultimately the point is that beliefs assist the critical mind in working creatively towards an authentic spirituality in a decisive, but positive manner. A discipline flourishes not only when it is critical, but when it is critical about matters that matter and that are meaningful. Beliefs and theology provide the type of input that prevents the impression that Christianity "be thought of as a vague and muddled set of attitudes or values" (McGrath 1999:28).

In spirituality the critical mind need not exclude theology. They belong together in a creative, tensive manner. In fact, in spirituality, as the sophisticated nature of contextual spiritualities has indicated, we may even need more reason and more theology.

\section{BIBLIOGRAPHY}

Amirtham S \& R Pryor (EDs.)

[1989]. The invitation to the feast of life. Resources for spiritual formation in theological education. World Council of Churches. Programme on theological education.

ASTELL A W

1994. Divine representations. Postmodernism and spirituality. New York: Paulist.

Boff L \& C 1984. Salvation and liberation. In search of a balance between faith and politics. Maryknoll: Orbis.

BUSSMANN C

1985. Who do you say? Jesus Christ in Latin American theology. Maryknoll: Orbis.

Cady S, Ronan M \& TAussig $\mathrm{H}$

1986. Sophia. The future of Feminist spirituality. San Francisco: Harper \& Row.

CAPRIO B

1982. The woman sealed in the tower. A psychological approach to feminine spirituality. New York/Ramsey: Paulist. 


\section{Cousins E H}

1990. What is Christian spirituality? In: B.C. Hanson (ed.), Modern Christian spirituality. Methodological and historical essays (Atlanta: Scholars), pp. 39-51.

\section{Croatto J S}

[1989]. Spiritual formation and critical study. In: S. Amirtham \& R. Pryor (eds.), The invitation to the feast of life. Resources for spiritual formation in theological education (World Council of Churches. Programme on theological education), pp. 12-17.

\section{DECOCK P B}

2005. The value of pre-modern interpretation of Scripture for contemporary Biblical Studies. Neotestamentica 39:57-74.

\section{De Villiers P G R}

1993. The Bible and the struggle (for power). Scriptura 27:1-28.

1999a. The polemical task of feminist spiritualities. Scriptura 70:195-209.

1999b. The rise and nature of feminist spirituality. HTS 55:1-25.

\section{EIRE C M N}

1990. Major problems in the definition of spirituality as an academic discipline.

In: B. C. Hanson (ed.), Modern Christian spirituality. Methodological and historical essays (Atlanta: Scholars Press), pp. 53-64.

\section{Fabella V, LeE P K H, Kwang-Sun SuH D (Eds.)}

1992. Asian Christian spirituality. Reclaiming traditions. New York: Orbis.

\section{Fox M (ED.)}

1981. Western spirituality. Historical routes, ecumenical roots. Santa Fe: Bear.

\section{GALILEA S}

1988. The way of the living faith. London: Collins.

\section{HANSON B C}

1990. Modern Christian spirituality. Methodological and historical essays. Atlanta: Scholars Press.

1982. Christian spirituality and spiritual theology. Dialog 21:207-212.

\section{INDIAN PREPARATORY GROUP}

1992. An Indian search for a spirituality of liberation. In: V. Fabella, P.K.H. Lee \& D. Kwang-sun Suh (eds.), Asian Christian spirituality. Reclaiming traditions. (New York: Orbis), pp. 70-85.

\section{JANTZEN G M}

1995. Power, gender and Christian mysticism. Cambridge: Cambridge University Press. Cambridge Studies in Ideology and Religion 8.

\section{MAAS R \& O’DONNELL G} 1990. Spiritual traditions for the contemporary church. Nashville: Abingdon. 


\section{MACQUARRIE J}

1986. Prayer and theological reflection. In: C. Jones, G. Wainwright \& E. Yarnold (eds.), The study of spirituality (London: SPCK), pp. 584-8.

McGinn B, Meyendorff J \& LeClerQ J 1988. Christian spirituality. Origins to the twelfth century. New York: Crossroad. World Spirituality. An Encyclopedic History of the Religious Quest 16.

\section{MCGRath A E}

1994. Spirituality in an age of change. Rediscovering the spirit of the Reformers. Grand Rapids: Zondervan.

1999. Christian spirituality. An introduction. Oxford: Blackwell.

\section{Min A K}

1989. Dialectic of salvation. Issues in Theology of Liberation. Albany: State University of New York.

\section{Nussbaum M C}

1986. The fragility of goodness. Luck and ethics in Greek tragedy and philosophy. Cambridge: Cambridge University Press.

1994. The therapy of desire. Theory and practice in Hellenistic ethics. Princeton: Princeton University Press.

\section{RAYAN S}

1992. The search for an Asian spirituality of liberation. In: V. Fabella, P.K.H. Lee \& D. Kwang-sun Suh (eds.), Asian Christian spirituality. Reclaiming traditions (New York: Orbis), pp. 11-30.

\section{RHOADS D}

2005. From every people and nation. The Book of Revelation in intercultural perspective. Minneapolis: Fortress.

\section{RoteN J G}

1994. The Marian counterpoint of post-modern spirituality. In: A.W. Astell (ed.), Divine representations. Postmodernism and spirituality. New York: Paulist Press.

\section{RUETHER R R}

1981. Patristic spirituality and the experience of women in the early church. In: M. Fox (ed.), Western spirituality. Historical routes, ecumenical roots (Santa Fe: Bear), pp. $140-163$.

\section{SCHNEIDERS S M}

1990. Scripture and spirituality. Christian Spirituality 1:1-20.

1990. Spirituality in the academy. In: B.C. Hanson (ed.), Modern Christian spirituality. Methodological and historical essays (Atlanta: Scholars, American Academy of Religion. Studies in Religion 62), pp. 15-37. 


\section{SCHÜSSLER FIORENZA E}

1983. You are not to be called father; Early Christian history in a feminist perspective. In: N.K. Gottwald (ed.), The Bible and liberation. Political and social hermeneutics (Maryknoll: Orbis), pp. 394-417.

SOBRINO J

1985. The spirituality of liberation. Toward political holiness. Maryknoll: Orbis.

1984. The true church and the poor. London: SCM.

SOLOMON R C

2002. Spiritualiteit voor Sceptici. Ten Have: s.l.

\section{TAMEZ E}

[1989]. Spiritual formation and critical study: a case study. In: S. Amirtham \& R. Pryor (eds.), The invitation to the feast of life. Resources for spiritual formation in theological education (World Council of Churches. Programme on theological education), pp. 121-35.

\section{VERHOEVEN A}

1989. The concept of God: a feminine perspective. In: E. Tamez (ed.), Through her eyes. Women's theology from Latin America (Maryknoll: Orbis), pp. 49-55.

\section{WAAIJMAN K}

2002. Spirituality. Forms, foundations and methods. Leuven: Peeters.

Keywords

Reason

Rationalism

Emotions

Intellectualism

Theology

Spirituality
Trefwoorde

Rede

Rasionalisme

Emosies

Intellektualisme

Teologie

Spiritualiteit 